\title{
Editorial
}

\section{Que fazer?}

Diante da pandemia do novo coronavírus que assola o país segundo dados oficiais, 173 mil mortos em novembro de $2020-$, o ProgramadePós-GraduaçãoemComunicação,daUniversidadeEstadual de Londrina, resolveu adotar algumas mudanças, como, por exemplo, a reestruturação do calendário de atividades, buscando assim a defesa do ensino de qualidade. A partir de um diálogo efetivo entre professores e estudantes, o Programa repensou datas, modelos e conteúdos. Neste sentido, o Programa utilizou a disciplina "Tópicos Especiais em Comunicação Visual" para oferecer um conteúdo exclusivamente dedicado a pensar a comunicação em tempos de pandemia. E é neste mesmo espírito que convidamos nossos colaboradores a submeter artigos voltados para esse momento conturbado. Esperamos encontrar as próximas edições mobilizadas diante desse desafio crítico.

Abrimos esta edição com o artigo "Fotojornalismo no Brasil em 1968: a ditadura e o povo no olhar de Evandro Teixeira", de Janayna da Silva Ávila. Analisando cinco fotografias de autoria do fotógrafo Evandro Teixeira, publicadas no Jornal do Brasil, em 1968, a autora mostra como o corpo político é o elemento central desse importante documento visual. Em "Entre verdade e encenação: o fotojornalismo entre o documento e a expressão", as autoras Laura Duarte Uliana e Simonetta Persichetti discutem duas correntes de pensamento sobre a imagem fotográfica, a fotografia-documento e a fotografiaexpressão, como pensadas por André Rouillé, e verificam suas 
influências no fotojornalismo. As autoras também analisam dois produtos: a revista Life e a agência Magnum, cada uma como principal expoente das respectivas correntes de pensamento.

A partir de ferramentas de reconhecimento de emoções por expressão facial, os autores Leão Renato Pinto Serva Neto, Eduardo Eugênio Spers, Norval Baitello Júnior e Carlos Augusto Lopes da Costa identificam sentimentos despertados pela visão de um conjunto de imagens de guerra. Entre os resultados apresentados pelo artigo "Fotos de guerra causam dependência? Um estudo com reconhecimento facial de emoções", os autores especulam sobre uma atração por imagens de conflito que se mantém crescente enquanto dura a oferta.

Ao questionarem como os professores de fotojornalismo percebem as novas Diretrizes Curriculares Nacionais, as autoras Dayana Estevam Moreira e Glaucia da Silva Brito identificam possíveis barreiras para o equilíbrio entre teoria e prática no ensino da disciplina e refletem sobre as novas diretrizes como aliadas para a transposição destes obstáculos. $\mathrm{O}$ artigo "A teoria versus a prática e as novas Diretrizes Curriculares Nacionais no ensino do fotojornalismo" mostra que, apesar das dificuldades, os docentes preocupam-se constantemente com o equilíbrio entre teoria e prática no ensino da disciplina. Ainda abordando o problema da educação, mas desta vez enfocando as relações entre a escola e as multiplicidades do ato fotográfico, o artigo "Espelho quebrado: fotografia e fragmentação" traz a figura do título para refletir sobre as fragmentações da contemporaneidade, contrapondo a imagem ideal e o estilhaço multifacetado. Baseada em autores como Deleuze, Guattari e Focault, as autoras Adrise Ferreira de Souza e Paola Basso Menna Barreto Gomes Zordan traçam algumas considerações em torno 
do conceito de fora e da imagem enquanto força assignificante.

Fernando Andacht e Thiago Garcia Martins comparam dois vídeos publicitários, ambos lançados em 2013 - Eduardo e Mônica, da marca Vivo, e Retratos da Real Beleza, da marca Dove -, buscando mostrar como suas narrativas são construídas no ambiente digital. $\mathrm{O}$ artigo "A representação do real como argumento de venda: uma análise comparativa de vídeos publicitários" realiza uma análise literária da mimese narrativa para refletir sobre como estratégias tradicionais ainda são adotadas, apesar de divergências importantes entre os vídeos.

Ao analisar determinas imagens hegemônicas de grupos sociais da Bolívia e do Peur, o artigo "El gusto por los otros: turismo, fotografía y patrimonio cultural en el contexto andino", dos autores Juan Pablo Silva-Escobar e Valentina Raurich, mostra como o turismo, o patrimônio cultural e a fotografia constituem uma tríade que contribui para a idealização da alteridade, apresentando certas comunidades como atrações imperdíveis e como mundos exóticos presos em uma etnicidade convertida em fetiche.

Encerramos esta edição com o artigo "Imagens autênticas: corpo, contágio e fotografia política nos tempos do Instagram", de Paolo Demuru. Baseado na semiótica discursiva de Greimas e na sociossemiótica de Landowski, o autor analisa as estratégias discursivas que se utilizam do retrato do corpo no Instagram a fim de construir lideranças políticas aparentemente autênticas. A hipótese do artigo entende que o efeito de autenticidade promovido por tais imagens funda-se em um contágio sensível que reproduz um jogo de espelhamento recíproco entre os líderes e seus seguidores. 